\title{
The Impact of Internal Marketing on Service Quality, Perceived Value, Consumer Satisfaction and Loyalty in the Service Sector
}

\author{
Rakotovao Manovosoa Finaritra ${ }^{1}$, Rakotomahenina Pierre Benjamin ${ }^{2}$ \\ ${ }^{1}$ Department of Business and Trade Management Engineering, Institut Supérieur de Technologie d'Antananarivo, Madagascar \\ ${ }^{2}$ Department of Management, Faculty of Economics, Management and Sociology, University of Antananarivo, Madagascar
}

\begin{abstract}
This article proposes to integrate internal marketing, perceived quality, perceived value, satisfaction and behavioural intention in the same model. The study was conducted with 200 healthcare staff and 200 patients. First, the results indicate the influence of internal marketing dimensions on perceived quality and satisfaction. In a second step, it turns out that perceived quality influences satisfaction and perceived value, which in turn impacts satisfaction. Finally, there is a relationship between, on the one hand, satisfaction and behavioural intention and, on the other hand, the perceived value and behavioural intention of consumers.
\end{abstract}

KEYWORDS: Internal marketing, perceived quality, trust, satisfaction, behavioural intention.

\section{INTRODUCTION}

One of the goals of marketing is to satisfy consumers. Indeed, for the latter, the value of a product lies in its ability to satisfy their needs. Whether it is for manufactured goods or services, consumer needs are satisfied by various attributes of the offer. However, given the simultaneous nature of the production and consumption of services, combined with relatively closer contact with consumers, it can be said that the marketing and management of services has a unique and particular character.

Indeed, in the service sector, the interaction between the employee and the customer is crucial for the experimentation of the service offer [1]. From this perspective, contact employees play an important role in customer satisfaction. It is attested that the quality of service, the efficiency of distribution, the efficiency of communication depend directly on contact employees. Thus, greater attention to employee-customer interactions can result in improved perceptions of service quality, customer satisfaction and the purchase intent of service customers.

Highlighting the importance and involvement of employees in the marketing of services refers to internal marketing. Indeed, internal marketing is a management philosophy and a set of activities that consider employees as internal customers and jobs as internal products. It then strives to offer internal products to satisfy the needs and desires of internal customers, while meeting the organization's objectives [2]. From this perspective, internal marketing has as its main objective the development of customer-oriented staff, and focuses primarily on employee development by emphasizing the importance of recognizing their contribution.

Perceived value is undoubtedly one of the key marketing themes. Its importance is recognized both in the business world and in the academic world. In the business world, perceived value is a source of competitive advantage and profit because it is linked to marketing variables such as satisfaction [3]. Moreover, it is strongly linked to consumers' purchasing intentions. In the academic world, the abundance of research testifies to the importance of the subject.

Although perceived value and internal marketing are recognized as important in explaining consumer satisfaction, no research attempts to integrate these two concepts into a single model. Thus, the objective of this research is to combine perceived value, perceived quality and internal marketing in a single model to explain consumer satisfaction and behavioural intent in the context of services. On the theoretical level, the aim is to compensate for the relative shortcomings revealed in the current literature. A deepening of the too few if not almost non-existent studies around a satisfaction model integrating at the same time perceived value, quality and internal marketing is necessary. Moreover, in the healthcare industry, despite the potential importance of the concept, it is largely neglected in the strategic considerations of healthcare providers. Methodologically, it is interesting to investigate in other fields as well as other cultures to improve the validity of research around these constructs. 


\section{The Impact of Internal Marketing on Service Quality, Perceived Value, Consumer Satisfaction and Loyalty in the Service Sector}

This article is organized in five parts. After a review of the literature on internal marketing, value, quality, satisfaction and intent, we present the conceptual research model and the hypotheses that arise from it. We then present the methodology and results discussed in the last part.

\section{LITERATURE REVIEW}

After an overview on the concept of internal marketing, perceived value and quality, this part deals with the concept of satisfaction. The concept of behavioural intention is dealt with at the end of the section.

\section{A. Internal marketing}

The concept of internal marketing originated in the 1970s [4]. Since then, the concept has become more and more important in research and is increasingly adopted and exploited within companies. From an internal marketing perspective, organizations need to view their employees as internal consumers [4]. According to this principle, internal marketing is more important than conventional external marketing [5]. In this sense, it must precede external marketing as the key to service excellence and successful external marketing [6].

Indeed, in service companies, front-line employees are essential to the success of organizations because they are in direct contact with external clients. As a result, they have a significant impact on the quality of service provided and customer satisfaction [7]. The growing recognition of the importance of the role of employees in the service industry has led service organizations to adopt internal marketing [7]. In order to encourage employees to provide excellent service to the external customer, organizations must treat employees as internal customers and thereby satisfy their needs. In this sense, internal marketing can be used to change employees' attitudes and behaviours. In addition, it can improve organizational commitment, task participation, motivation, and job satisfaction of employees [4].

In the literature, there is no consensus definition of internal marketing, sometimes it is defined as a philosophy, sometimes as a method, and sometimes as a process. From the first perspective, [2] define it as a management philosophy and set of activities that consider employees as internal customers and jobs as internal products. Internal marketing strives to offer internal products to satisfy the needs and desires of internal customers, while meeting the goals of the organization. According to the second perspective, it is a method that organizations successfully use to hire, retain, and motivate employees to provide better service to customers [6]. It is defined as the process of attracting, developing, motivating, and retaining skilled employees through internal (job-related) products that meet their needs [8].

Like its definition, there is no consensus on the dimensions that make up internal marketing. While Tansuhaj et al. [2] support a five-dimensional concept: recruitment, training, motivation, communication and employee retention, Huang et al. [4] advance three dimensions: internal communication, training and internal market research. Other conceptions of internal communication include a two-dimensional concept that integrates formal and informal internal communication [9].

\section{B. Perceived quality}

Perceived quality has always been at the center of marketing research, both in the corporate and academic worlds. In the business world, it is recognized as important in the commercial success of the company and in the search for competitive advantage. In fact, it has an impact on the costs and financial performance of the company. Particularly, in healthcare services, patients' perception of the quality of services is a key determinant of the provider's success because of its main role in patient satisfaction [3]. As far as the academic world is concerned, perceived quality is one of the themes most mobilized by marketing researchers in recent years.

Despite the importance of quality in the marketing literature, it is difficult to find a universal definition of the concept. For some, it is defined as the customer's perception of the overall quality or superiority of a product or service in relation to its intended use, in comparison with the alternatives available. While for others, it refers to an overall evaluation of the service that results from a comparison between, on the one hand, customers' expectations regarding service performance in general and, on the other hand, the evaluation of this performance for a particular service developed by a given company [10]. Nevertheless, an analysis of all these definitions brings out the idea of a confrontation between a prior expectation of the consumer and his impressions of a service. Thus, if the quality of the service provided exceeds expectations, the perceived quality is high, on the other hand, if it is below expectations, the perceived quality is low.

\section{Satisfaction}

For many years, satisfaction has been a key marketing concept for both the business and academic worlds. In the corporate world, it is part of a strategic perspective because it is strongly linked to post-purchase consumer behaviors such as loyalty [11]. In particular, in the context of healthcare services, patient satisfaction could be manifested through positive word-of-mouth and have a positive impact on the financial results of the institution [3]. In addition, it influences the outcome of medical practices [12]. For these reasons, patient satisfaction measurement is an integral part of the strategic processes of healthcare 


\section{The Impact of Internal Marketing on Service Quality, Perceived Value, Consumer Satisfaction and Loyalty in the Service Sector}

organizations [3]. In the academic world, its importance is evidenced by the increasing number of investigations on the subject over the years.

The literature puts forward two different conceptions of satisfaction: one refers to a specific transaction and the other to an overall assessment [1], [13]. According to the first perspective, it is defined as a judgment following a specific transaction. In this sense, it is inherent to the most recent transaction. On the other hand, it is an evaluation or experience in reaction to a particular transaction with a product, episode or service. According to the second idea, it is an evaluation based on all purchases and consumption experiences of a product or service. In this sense, it is an addition of all the satisfactions felt at the end of all the services received. This cumulative perspective is more interesting than a transactional perspective for assessing subsequent consumer behaviour.

\section{Perceived value}

Driven by ever more demanding consumers, ever more intense competition and ever more rapid technological change, companies are constantly trying to find new strategies to gain and maintain a competitive advantage. On the other hand, consumers, on the one hand, seem to be more and more rational, and on the other hand, they are now faced with a multitude of choices. In this new context, the concept of the customer-focused, value-adding company in relation to the competition finds all its relevance. The introduction of perceived value into the company's strategy makes this customer-oriented approach effective. Indeed, the value perceived by the customers is the basis for comparison and selection between the offers on the market.

Although the importance of customer value is recognized in the literature, investigations around the concept are fragmented and definitions of value diverge. On the one hand, it is defined as an overall assessment made by the consumer of the usefulness of a product between what is received and what is due [14]. On the other hand, it refers to the difference in value perceived by customers between the quality or benefits of the product/service and the sacrifice made in paying the price. According to yet other ideas, it refers to an emotional bond established between a customer and a producer after the customer has experienced a product or service produced by a provider. Despite these different conceptions of value, there is some consensus: first, perceived value is not objectively determined by providers or other stakeholders, but refers to what the client perceives. Second, value perception processes generally involve a trade-off between what clients receive, such as quality, benefits, and public services, and what they sacrifice, such as price, opportunity cost, maintenance, and training costs.

\section{E. Behavioural intention}

Behavioural intention refers to people's beliefs about what they intend to do in a certain situation [15]. Behavioural intention is conceptualized as a proxy indicator for actual behaviour. On this basis, according to the theory of reasoned action [15], attitude (i.e., an individual's positive or negative assessment of a consumption experience) influences the intention to perform an activity, which in turn determines actual behaviour.

From this perspective, certain behaviours indicate a customer's attachment to a business. These specific indicators of favourable behavioural intentions are manifested by saying positive things about the business, recommending it to others, and remaining loyal to it. Conversely, unfavourable aspects of behaviour are manifested by complaining, turning to competing firms, or decreasing the volume traded with the firm in question [16].

\section{RESEARCH MODELING AND HYPOTHESIS}

Empirical investigations confirm a positive relationship between internal marketing and consumer satisfaction [2] and between internal marketing and service quality [17]. Indeed, internal marketing acts in a positive way with employees who, in turn, will make the necessary efforts to meet consumer needs. For the purposes of this research, internal marketing refers to service training programs, performance bonuses, and a vision of service excellence [6]. These ideas are based on the following assumptions:

H1a: Service training programs positively influence service quality.

H2a: Performance incentives are positively related to service quality.

H3a: The vision of service excellence positively influences service quality.

$\mathrm{H} 1 \mathrm{~b}$ : Service training programs positively influence customer satisfaction.

$\mathrm{H} 2 \mathrm{~b}$ : Performance incentives are positively linked to customer satisfaction.

$\mathrm{H} 3 \mathrm{~b}$ : The vision of service excellence positively influences customer satisfaction.

Although the link between perceived quality and satisfaction has been the subject of numerous investigations, a question remains unresolved as to the place of both in the link. Perceived quality is sometimes presented as an antecedent to satisfaction, and sometimes it results from satisfaction [11]. In the present research, we align ourselves with the idea that quality is an antecedent to satisfaction [18]. Hence the following hypothesis:

H4: Quality positively influences satisfaction.

Value is at the heart of what consumers look for in an exchange [19]. Although there is no consensual definition of value, it can be understood as the consumer's subjective perception of the value of an activity or object, taking into account the benefits 


\section{The Impact of Internal Marketing on Service Quality, Perceived Value, Consumer Satisfaction and Loyalty in the}

\section{Service Sector}

and costs related to consumption [19]. According to this perspective, a high level of quality is not a precondition for value because a reduction in quality can be compensated for by lower costs. However, our ideas are consistent with previous investigations that point to a positive relationship between perceived quality and perceived value [18]. These ideas support the following hypothesis:

H5: Perceived quality positively influences perceived value.

In addition to the link between perceived quality and satisfaction, perceived value is considered a determinant of satisfaction [3], [18]. Indeed, the two main determinants of satisfaction are perceived value and quality [3], [18]. This leads to the following hypothesis:

H6: Perceived value positively influences satisfaction.

Satisfaction can reinforce the customer's decision to re-experience a particular service. From this perspective, the more satisfied the customer is, the higher the intention to buy back and recommend the service to the provider. Moreover, empirical investigations confirm the link between satisfaction and the consumer' behavioural intention [18]. Hence the formulation of the following hypothesis:

H7: Satisfaction positively influences the consumer's behavioural intention.

As well as the link between satisfaction and behavioural intention, there also seems to be a link between perceived value and the consumer's behavioural intention [20]. This leads to the following hypothesis:

H8: Perceived value positively influences the consumer's behavioural intention.

The overall research model is as follows:

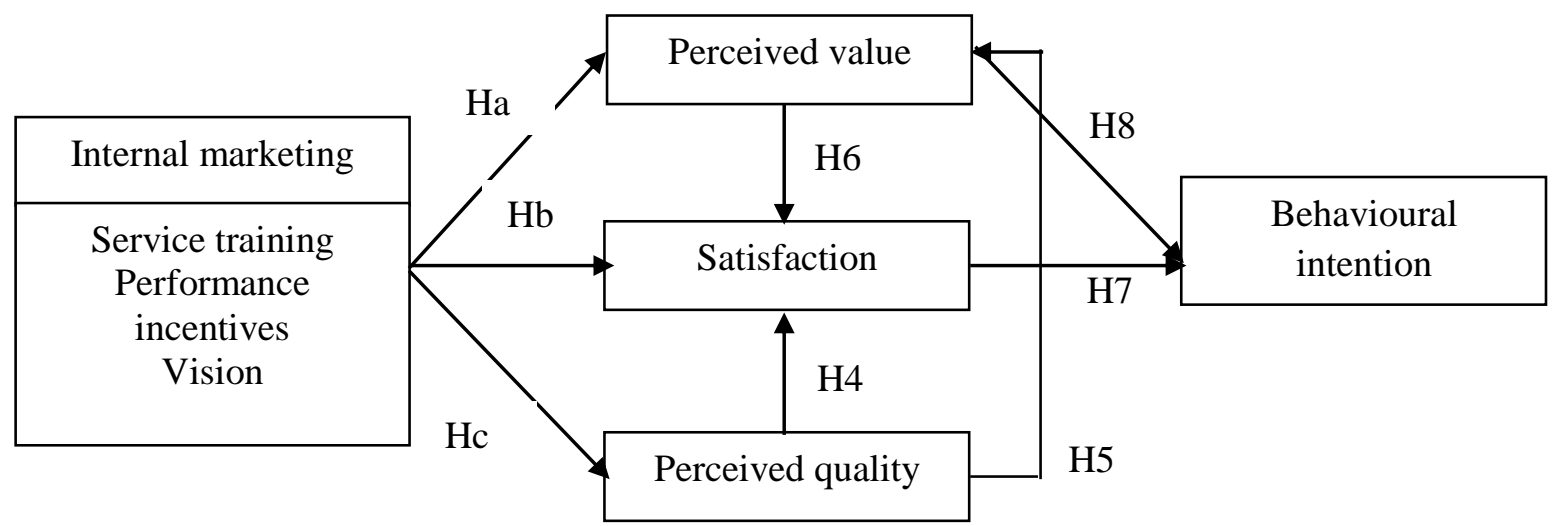

Figure 1. The global research model

\section{METHODOLOGY}

This part presents the measuring instruments for each of the constructions. Sampling and data collection, as well as the method of analysis are presented.

\section{A. Measures}

The measurement scales used are all taken from the literature. We have adapted them according to the context of the study. The items for internal marketing are initiated by Tsai and Tang [6],. Quality measurement is adapted from Wu [21], perceived value, satisfaction and behavioural intention are inspired by the work of [3]. Table 1 illustrates the different definitions used for each construct.

\section{B. Subjects and procedure}

Prior to data collection, the questionnaire was pre-tested with 10 caregivers and 10 patients. The final version of the questionnaires was then administered face-to-face. The questionnaire on internal marketing was distributed to 200 health workers (doctors and nurses) in public and private hospitals in Madagascar. The questionnaire on perceived quality, perceived value and satisfaction was distributed to 200 patients. According to Janssens et al. [22], to ensure the reliability of a structural equation model, the number of responses must be 5 to 10 times higher than the number of items. In this research, the scale with the highest number of items is the scale relating to the training program. The minimum number required to validate the scale is at least 35 responses, i.e. 5 times the 7 items. Loehlin [23], for his part, puts forward the idea of a sample of 100 to 200 individuals, and concludes that the model behaves correctly if the sample size meets this condition. Given these methodological recommendations, the difficulties related to both the survey and the availability of individuals to be questioned, and the length of our questionnaire, we interviewed 200 individuals. 
The Impact of Internal Marketing on Service Quality, Perceived Value, Consumer Satisfaction and Loyalty in the Service Sector

Table 1. Constructs definitions

\begin{tabular}{|c|l|l|}
\hline Constructs & \multicolumn{1}{|c|}{$\begin{array}{l}\text { Definition } \\
\text { Refers to three dimensions: service } \\
\text { training programs performance } \\
\text { incentives and the vision of service } \\
\text { excellence. }\end{array}$} & Tsai et Tang [6] \\
\hline Perceived quality & $\begin{array}{l}\text { Comparison of customer } \\
\text { expectations with their perception of } \\
\text { actual service performance }\end{array}$ & Wu [21] \\
\hline Perceived value & $\begin{array}{l}\text { The overall assessment by the } \\
\text { patient in relation to the perception of } \\
\text { what is received and what is given. }\end{array}$ & Choi et al. [3] \\
\hline Satisfaction & $\begin{array}{l}\text { The consumer's response to the } \\
\text { evaluation of the gap between previous } \\
\text { expectations and the actual } \\
\text { performance of the product as } \\
\text { perceived after consumption. }\end{array}$ & Choi et al. [3] \\
\hline Behavioral intention & $\begin{array}{l}\text { Refers to willingness to recommend, } \\
\text { intention to redeem and positive word- } \\
\text { of-mouth. }\end{array}$ & Choi et al. [3] \\
\hline
\end{tabular}

\section{Statistical analysis}

The data obtained are processed with SmartPLS 3 software. First, the measurement scale was tested, then a modeling under structural equation allowed to test the hypotheses put forward.

\section{RESULT}

After presenting the reliability and validity tests of the measurement scales, this section discusses the results of the structural model test.

\section{A. Measurement model}

Before testing the structural model, the reliability, convergent and discriminant validity of the constructs must be established.

Table 2. Scales measurement

\begin{tabular}{|c|c|c|c|}
\hline Construct/measurement & $\lambda$ & Fiability & AVE \\
\hline Service training programmes & & & \\
\hline We prepare to perform well. & 0.731 & \multirow{7}{*}{0.907} & \multirow{7}{*}{0.584} \\
\hline $\begin{array}{l}\text { Our organization views the development of knowledge and skills in } \\
\text { employees as an investment rather than a cost. }\end{array}$ & 0.821 & & \\
\hline $\begin{array}{l}\text { Skill and knowledge development of employees happens as an ongoing } \\
\text { process in our hospital. }\end{array}$ & 0.789 & & \\
\hline $\begin{array}{l}\text { The hospital teaches us why we should do things and not just how we } \\
\text { should do things. }\end{array}$ & 0.725 & & \\
\hline The organization goes beyond training and educates employees as well. & 0.795 & & \\
\hline In this organization, we are properly trained to perform our service roles. & 0.716 & & \\
\hline $\begin{array}{l}\text { This organization has the flexibility to accommodate the differing needs } \\
\text { of employees. }\end{array}$ & 0.766 & & \\
\hline \multicolumn{4}{|l|}{ Performance incentives } \\
\hline $\begin{array}{l}\text { Our performance measurement and reward systems encourage } \\
\text { employees to work together }\end{array}$ & 0.945 & \multirow{3}{*}{0.963} & \multirow{3}{*}{0.896} \\
\hline $\begin{array}{l}\text { We measure and reward employee performance that contributes to our } \\
\text { organization's vision. }\end{array}$ & 0.938 & & \\
\hline $\begin{array}{l}\text { In our organization, employees who provide excellence service are } \\
\text { rewarded for their efforts. }\end{array}$ & 0.957 & & \\
\hline \multicolumn{4}{|l|}{ Vision about excellence service } \\
\hline Our organization offers us a vision that we can believe in. & 0.862 & \multirow{3}{*}{0.943} & \multirow{3}{*}{0.735} \\
\hline Managers communicate our organization's vision well to us. & 0.912 & & \\
\hline The organization uses the data which it gathers from employees to & 0.714 & & \\
\hline
\end{tabular}


The Impact of Internal Marketing on Service Quality, Perceived Value, Consumer Satisfaction and Loyalty in the Service Sector

\begin{tabular}{|c|c|c|c|}
\hline \multicolumn{2}{|l|}{ improve our jobs, and to develop the strategy of the organization. } & & \\
\hline $\begin{array}{l}\text { Our organization communicates to employees the importance of their } \\
\text { service roles. }\end{array}$ & 0.854 & & \\
\hline $\begin{array}{l}\text { The organization places considerable emphasis on communicating with } \\
\text { us. }\end{array}$ & 0.855 & & \\
\hline Qualité perçue & & & \\
\hline Physical facilities, equipment and appearance of personnel (Tangible) & 0.923 & \multirow{5}{*}{0.948} & \multirow{5}{*}{0.785} \\
\hline $\begin{array}{l}\text { Ability to deliver the promised service confidently and accurately } \\
\text { (Responsiveness) }\end{array}$ & 0.851 & & \\
\hline Good will to respond to consumers and offer prompt service (Reliability) & 0.863 & & \\
\hline $\begin{array}{l}\text { Competent and courteous employees and their ability to inspire } \\
\text { confidence (Assurance) }\end{array}$ & 0.930 & & \\
\hline $\begin{array}{l}\text { Consideration, individualized attention that the company gives to its } \\
\text { consumers (Empathy) }\end{array}$ & 0.862 & & \\
\hline \multicolumn{4}{|l|}{ Valeur perçue } \\
\hline The amount of money I paid for the care was appropriate. & 0.973 & \multirow[b]{2}{*}{0.974} & \multirow[b]{2}{*}{0.949} \\
\hline $\begin{array}{l}\text { The quality of the medical service I received was worth more than what I } \\
\text { paid. }\end{array}$ & 0.975 & & \\
\hline \multicolumn{4}{|l|}{ Satisfaction } \\
\hline How satisfied were you with the treatment you received in the hospital? & 0.958 & \multirow{2}{*}{0.955} & \multirow{2}{*}{0.915} \\
\hline How satisfied were you with your decision to use the hospital? & 0.955 & & \\
\hline \multicolumn{4}{|l|}{ Behavioural intentions } \\
\hline I will recommend that other people use this hospital. & 0.933 & \multirow{3}{*}{0.944} & \multirow{3}{*}{0.949} \\
\hline $\begin{array}{l}\text { If I needed medical services in the future, I would consider this hospital } \\
\text { as my first choice. }\end{array}$ & 0.923 & & \\
\hline I will tell other people good things about this hospital. & 0.907 & & \\
\hline
\end{tabular}

The reliability test gave results greater than 0.7 (between 0.714 and 0.975 ), an acceptable threshold according to Nunnally and Bernstein [24], which confirms the reliability of the measurement scales used [25]. Concerning the validity test, Bagozzi and $\mathrm{Yi}$ [26] suggest that convergent validity is ensured by $\lambda$ above 0.7 . Table 2 shows that all of the $\lambda$ are above their recommendations. Furthermore, the mean extracted variances (AVE) are greater than 0.5, which makes it possible to establish the convergent validity of the constructs [25]. With regard to discriminant validity, it is established when the square root of the mean extracted variance (AVE) is greater than each of the correlations between constructs [25]. The results in Table 3 show that the conditions for discriminant validity are met.

Table 3. Discriminant validity test

\begin{tabular}{|c|c|c|c|c|c|c|c|}
\hline & 1 & 2 & 3 & 5 & 5 & 6 & 7 \\
\hline Training program & 0.764 & & & & & & \\
\hline Performance & 0.695 & 0.947 & & & & & \\
\hline Behavioral intention & 0.699 & 0.721 & 0.921 & & & & \\
\hline Quality & 0.709 & 0.674 & 0.697 & 0.886 & & & \\
\hline Satisfaction & 0.618 & 0.636 & 0.855 & 0.714 & 0.956 & & \\
\hline Perceived value & 0.578 & 0.634 & 0.792 & 0.706 & 0.809 & 0.974 & \\
\hline Vison & 0.609 & 0.605 & 0.704 & 0.783 & 0.644 & 0.637 & 0.857 \\
\hline
\end{tabular}

\section{B. Structural model}

To evaluate the structural model, the coefficient of determination (R2) of each dependent variable, the structural coefficients $(\beta)$ and the level of significance (t-value) were examined. The values of R2 are above the recommended threshold of 0.10 (between 0.504 and 0.731) [27]. 
The Impact of Internal Marketing on Service Quality, Perceived Value, Consumer Satisfaction and Loyalty in the Service Sector

Table 4. Result of Structural Equation Model Estimates

\begin{tabular}{|l|l|l|l|l|l|}
\hline Path & Hypothesis & Structural coef & t-Value & p-value & Decision \\
\hline Training -> Quality & H1a & 0.545 & 8.322 & 0.000 & Accepted \\
\hline Performance -> Quality & H2a & 0.449 & 7.960 & 0.000 & Accepted \\
\hline Vison -> Quality & H3a & 0.659 & 10.685 & 0.000 & Accepted \\
\hline Training -> Satisfaction & $\mathrm{H} 1 \mathrm{~b}$ & 0.229 & 3.120 & 0.002 & Accepted \\
\hline Performance-> Satisfaction & $\mathrm{H} 2 \mathrm{~b}$ & 0.316 & 5.149 & 0.000 & Accepted \\
\hline Vison -> Satisfaction & $\mathrm{H} 3 \mathrm{~b}$ & 0.173 & 2.521 & 0.012 & Accepted \\
\hline Quality -> Satisfaction & $\mathrm{H} 4$ & 0.413 & 4.692 & 0.000 & Accepted \\
\hline Quality -> Value & $\mathrm{H} 5$ & 0.372 & 4.179 & 0.000 & Accepted \\
\hline Value -> Satisfaction & $\mathrm{H} 6$ & 0.491 & 5.456 & 0.000 & Accepted \\
\hline Satisfaction -> Intention & $\mathrm{H} 7$ & 0.855 & 42.311 & 0.000 & Accepted \\
\hline Value -> Intention & $\mathrm{H} 8$ & 0.372 & 4.495 & 0.000 & Accepted \\
\hline
\end{tabular}

This study was initiated to examine the relationship between the dimensions of internal marketing, perceived quality, perceived value, satisfaction and intentions. The results in Table 4 show that all three dimensions of internal marketing positively impact perceived quality and satisfaction $(\beta=0.545, \rho<0.005 ; \beta=0.449, \rho<0.005 ; \beta=0.659, \rho<0.005 ; \beta=0.229, \rho$ $<0.005 ; \beta=0.316, \rho<0.005 ; \beta=0.173, \rho<0.05)$. Therefore, $\mathrm{H} 1 \mathrm{a}, \mathrm{H} 2 \mathrm{a}, \mathrm{H} 3 \mathrm{a}$, as well as $\mathrm{H} 1 \mathrm{~b}, \mathrm{H} 2 \mathrm{~b}$ and $\mathrm{H} 3 \mathrm{~b}$ are confirmed. In addition, perceived quality has a positive impact on satisfaction $(\beta=0.413, \rho<0.005)$. As a result, $\mathrm{H} 4$ is confirmed. Similarly, perceived quality positively impacts perceived value $(\beta=0.372, \rho<0.005)$, which confirms $\mathrm{H} 5$. The same is true for the impact of perceived value on satisfaction $(\beta=0.491, \rho<0.005)$, therefore $\mathrm{H} 6$ is confirmed. Finally, satisfaction and perceived value have a positive impact on intention $(\beta=0.855, \rho<0.005 ; \beta=0.372, \rho<0.005)$, therefore confirming $\mathrm{H} 7$ and $\mathrm{H} 8$.

\section{DISCUSSION}

This study contributes to the current understanding of health care consumer behaviour in two ways. First, it allows us to test a model that integrates both internal marketing and perceived value in a satisfaction model. In fact, no study has attempted to integrate these variables in the same model. Second, our study satisfies the need to investigate these models in other cultures and health care systems.

First, the results show that the more the institution implements service training programs, the more clearly there is a clear vision of the services provided by the institution, the better the quality perceived by patients. Confirming other investigations [6], the results of this research imply that, first, internal marketing improves the knowledge and skills of health care staff to better respond to patient requests. Second, internal marketing increases nurses' willingness to provide high quality services by creating a vision of the service to be provided, thereby improving the quality of service provided by nurses.

Second, our results confirm the relationship between performance incentives and perceived quality. These results are contrary to what Tsai and Tang [6] found. One explanation is likely related to the socioeconomic context in which the study was conducted. Indeed, this research was conducted in Madagascar, one of the least developed countries. In this regard, given the high unemployment rate combined with difficult employment conditions, the various forms of incentives, especially financial ones, encourage people to work more.

Thirdly, the dimensions of internal marketing have a significant impact on patient satisfaction. These results confirm other ideas [7] that by meeting the needs of internal clients, i.e. the needs of the institution's staff, the institution improves its ability to meet the needs of external clients.

Fourth, the results reinforce the foundation of the causal sequence suggested by the multi-attribute attitude model: cognition (quality and value) - affect (satisfaction) - conation (behavioural intention).

First, perceived quality significantly impacts patient satisfaction. These results confirm other investigations attesting to the positive relationship between the two concepts [3]. In such situations, patients will opt for facilities with a high level of quality of care and service, which therefore seem to be the most able to satisfy their needs. Second, perceived value influences satisfaction. Thus, if the total value received is greater than the total sum of the sacrifices made by the patient, satisfaction is achieved. Otherwise, if the total value received is less than the sum of the sacrifices, there is dissatisfaction. Patients expect a certain level of service at the price they pay. Therefore, health care providers are encouraged to look for ways to reduce the perceived costs of monetary and non-monetary services and to increase perceived benefits to increase patient satisfaction. Furthermore, patient satisfaction has a significant relationship with patient behavioural intention. This finding is consistent with the results of previous studies in which satisfaction plays an important role in behavioural intentions [28]. In this sense, behavioural intention is based on a willingness to recommend the facility to others, a willingness to inform staff of the benefits of the hospital and a willingness to consider it as a first choice in the future. 


\section{The Impact of Internal Marketing on Service Quality, Perceived Value, Consumer Satisfaction and Loyalty in the Service Sector}

Finally, as well as satisfaction, perceived value also has a positive impact on consumers' behavioural intention. As a result, a study on a relational point of view between an institution and patients requires both satisfaction and perceived value to be taken into account. These two constructs are considered complementary. Indeed, satisfaction measures the level of what the provider currently offers on the market, as perceived by customers. It refers to a tactical level that provides indications to improve current products and services. On the other hand, perceived value refers to the future directions of the company. It refers to a strategic level. From this perspective, it aims to assess how to create value for customers, how to better meet customer needs and how to attract potential customers. On this basis, the results of our research confirm the importance of satisfaction in any marketing decision. As a result, the marketing system must not only integrate the measurement of satisfaction, but also of perceived value.

\section{MANAGERIALIMPLICATIONS}

In addition to the theoretical impacts, our results also have implications for health care institutions. First, the service climate determines the behaviour of individuals by influencing their thinking and perceptions about certain aspects of their environment. As a result, the service climate relative to the organization can influence and regulate employees' attitudes and behaviours towards clients. In addition, internal marketing improves service quality through the service climate in question. Dimensions of internal marketing such as service training help to foster the service climate. From this perspective, an investment in staff training is necessary. Updates in job-related techniques are certainly essential, but also other training such as communication and emotion management in order to improve not only the quality of service offered to patients, but also the relationship between staff.

Secondly, the company's vision, especially the service excellence to which the company aspires, must be effectively communicated to all staff. This leads employees to have a coherent and collective vision of the company's strategic as well as operational direction. In addition, it is essential that employees are aware of what they can do to contribute to the success of the organization. Thus, seminars, annual conferences, regular meetings between managers and employees must be set up.

Thirdly, it is essential that the company creates a work environment where employees feel motivated, leading them to focus more on customers. In order to achieve this, as a first step, systems are needed that motivate and contribute significantly to improving the organization's service quality. As well as surveys for consumers, not only for consumers, employees must also be surveyed for satisfaction on a regular basis. As a second step, staff rewards should be reviewed and modified based on the organization's performance. In addition, a reward system could be developed to encourage employees to share their ideas to improve the organization's operations. Rewards need not be purely financial; other forms of rewards may be more effective. Such actions can create an environment in which employees see tangible results from their efforts.

Fourth, it is recommended that the organization strive to implement staff suggestions wherever possible. In addition, as a result of staff surveys and suggestions, management should provide feedback on employee suggestions (within a suitable timeframe). By listening to its employees and acting on their ideas and suggestions, the organization makes them feel valued and improves their involvement and motivation.

Finally, regarding perceived quality; it is important to reassure patients that they will receive the desired level and quality of services when they are admitted to the facility. Providers should be attentive to the dimensions of perceived quality (tangibility, reliability, helpfulness, assurance, empathy).

First, the overall appearance of the hospital facilities and staff provides some tangible clues about the quality of services that patients can expect. One of the basic expectations of patients is probably the assurance of being in good hands. The sense of assurance is best conveyed by the skills, professionalism, commitment and efficiency of the staff. Thus, staff must demonstrate a high level of competence in every interaction and exchange with patients.

Patients also expect accurate responses at all stages of care. Staff need to be precise in their responses about diagnostic results, treatment procedures that the patient should follow, etc. Communication with patients requires special attention from health care facilities. Not only must there be open communication with patients, but also listening to them. Staff responsiveness is also required. Staff need to be more responsive and respond quickly to patients' needs. Indeed, there appears to be a relationship between waiting time and patient satisfaction [28].

Concerning helpfulness and empathy. A new type of relationship between caregiver and patient needs to be established. Apart from treating patients with courtesy, all dimensions of the person must be taken into consideration, but not only the patient aspect or the exclusively medical treatment of the disease. Caring for the whole person includes not only physical treatment, but also emotional and psychological support from the caregivers. In this respect, beyond the perceived quality aspect, an empathetic demonstration of care by the caregivers influences the outcome of the treatment in question [12]. In this respect, empathy is manifested by taking into account patients' lifestyles in the treatment plan in order to personalize and individualize care.

\section{CONCLUSION: LIMITATION AND FUTURE RESEARCH DIRECTIONS}

One of the limits of research undoubtedly comes from our conception of satisfaction, which is restricted to its cognitive dimension. It would be just as interesting to investigate the emotional dimension of the construct. On the other hand, we have 


\section{The Impact of Internal Marketing on Service Quality, Perceived Value, Consumer Satisfaction and Loyalty in the Service Sector}

limited ourselves to the functional component of perceived value. However, perceived value is also presented as a unifying concept, integrating both a functional and an emotional component. Future investigations should integrate this other dimension of perceived value.

In this perspective, it would be interesting to integrate emotional work into models of satisfaction and perceived quality. Emotional work refers to the regulation of emotions or the process of managing expressions and emotions. Indeed, emotional work not only impacts patient satisfaction, but also improves the work environment for healthcare staff [12].

\section{REFERENCES}

1) M. Rakotovao, J. Ranjatoelina, P. B. Rakotomahenina, and T. Solofomiarana, "The determinants of satisfaction in restoration: The role of the dimensions of justice, emotions and disconfirmation," International Journal of Multidisciplinary Research and Development, vol. 7, no. 12, pp. 116-124, 2020.

2) P. Tansuhaj, D. Randall, and J. McCullough, "A Services Marketing Management Model: Integrating Internaland External Marketing Functions," Journal of Services Marketing, vol. 2, no. 1, pp. 31-38, Jan. 1988, doi: 10.1108/eb024714.

3) K.-S. Choi, W.-H. Cho, S. Lee, H. Lee, and C. Kim, "The relationships among quality, value, satisfaction and behavioral intention in health care provider choice: A South Korean study," Journal of Business Research, vol. 57, no. 8, pp. $913-$ 921, Aug. 2004, doi: 10.1016/S0148-2963(02)00293-X.

4) Y.-T. Huang, S. Rundle-Thiele, and Y.-H. Chen, "Extending understanding of the internal marketing practice and employee satisfaction relationship: A budget Chinese airline empirical examination," Journal of Vacation Marketing, vol. 25, no. 1, pp. 88-98, Jan. 2019, doi: 10.1177/1356766718757270.

5) I.-S. Hwang and D. Chi, "Relationships among Internal Marketing, Employee Job Satisfaction and International Hotel Performance: An Empirical Study," The International Journal of Management, vol. 22, p. 285, 2005.

6) Y. Tsai and T.-W. Tang, "How to improve service quality: Internal marketing as a determining factor," Total Quality Management \& Business Excellence, vol. 19, no. 11, pp. 1117-1126, Nov. 2008, doi: 10.1080/14783360802323479.

7) S. Mishra, "Internal Marketing- A Tool to Harness Employees' Power in Service Organizations in India," IJBM, vol. 5, no. 1, p. p185, Dec. 2009, doi: 10.5539/ijbm.v5n1p185.

8) L. Berry and A. Parasuraman, "Marketing Services: Competing Through Quality," 1991.

9) W. M. To, E. F. Martin, and B. T. W. Yu, "Effect of management commitment to internal marketing on employee work attitude," International Journal of Hospitality Management, vol. 45, pp. 14-21, Feb. 2015, doi: 10.1016/j.ijhm.2014.11.002.

10) M. Jougleux, "Enrichir l'approche théorique de la qualité dans les services: qualité du service et qualité de service," Recherche et Applications en Marketing (French Edition), vol. 21, no. 3, pp. 3-18, Sep. 2006, doi: 10.1177/076737010602100301.

11) R. Chumpitaz and V. Swaen, "La qualité perçue comme déterminant de la satisfaction des clients en business-tobusiness. Une étude empirique dans le domaine de la téléphonie," Recherche et Applications en Marketing (French Edition), vol. 19, no. 2, pp. 1-22, Jun. 2004, doi: 10.1177/076737010401900202.

12) T. J. Vogus and L. E. McClelland, "When the customer is the patient: Lessons from healthcare research on patient satisfaction and service quality ratings," Human Resource Management Review, vol. 26, no. 1, pp. 37-49, Mar. 2016, doi: 10.1016/j.hrmr.2015.09.005.

13) M. F. Rakotovao and G. Cliquet, "L'équité comme antécédent de la satisfaction: cas des taxis-brousses," Revue Internationale de Gestion et D'économie, vol. 1, no. 4, pp. 4-23, 2018.

14) K. B. Monroe, Pricing: Making "Profitable Decisions. New York: McGraw-Hill, 1990.

15) I. Ajzen and M. Fishbein, The Influence of Attitudes on Behavior, D. AD. Albarracin, B. T. Johnson, M. P. Zanna,. 1980.

16) Y. Namkung and S. C. (Shawn) Jang, "Effects of perceived service fairness on emotions, and behavioral intentions in restaurants," European Journal of Marketing, vol. 44, no. 9/10, pp. 1233-1259, Sep. 2010, doi: 10.1108/03090561011062826.

17) Richardson Brian A. and Grant Robinson C., "The Impact of Internal Marketing on Customer Service in a Retail Bank," International Journal of Bank Marketing, vol. 4, no. 5, pp. 3-30, Jan. 1986, doi: 10.1108/eb010791.

18) M. Rakotovao, J. Ranjatoelina, B. Rakotomahenina, and T. Rapanoël, "Music Quality, Perceived Value, Equity in Satisfaction and Behavioral Intentio in a Jazz Festival," EPRA, vol. 6, no. 12, pp. 358-365, 2020.

19) F. Lai, M. Griffin, and B. J. Babin, "How quality, value, image, and satisfaction create loyalty at a Chinese telecom," Journal of Business Research, vol. 62, no. 10, pp. 980-986, Oct. 2009, doi: 10.1016/j.jbusres.2008.10.015. 
The Impact of Internal Marketing on Service Quality, Perceived Value, Consumer Satisfaction and Loyalty in the

\section{Service Sector}

20) J. Hutchinson, F. Lai, and Y. Wang, "Understanding the relationships of quality, value, equity, satisfaction, and behavioral intentions among golf travelers," Tourism Management, vol. 30, no. 2, pp. 298-308, Apr. 2009, doi: 10.1016/j.tourman.2008.07.010.

21) C.-C. Wu, "The impact of hospital brand image on service quality, patient satisfaction and loyalty," African Journal of Business Management, vol. 5, no. 12, pp. 4873-4882, 2011.

22) W. Janssens, Ed., Marketing research with SPSS. Harlow, England ; New York: Prentice Hall/Financial Times, 2008.

23) J. C. Loehlin, Latent Variable Models: An Introduction to Factor, Path, and Structural Equation Analysis, Hillsdale. NJ: Lawrence Erlbaum, 2004.

24) J. Nunnally and I. Bernstein, Psychometric Theory, Mc Graw-Hill. New York, 1994.

25) C. Fornell and D. Larcker, "Evaluating Structural Equation Models with Unobservable Variables and Measurement Error," Journal of Marketing Research, vol. 18, no. 1, pp. 39-50, 1981.

26) R. R. Bagozzi and $\mathrm{Y} . \mathrm{Yi}$, "On the evaluation of structural equation models," Journal of the Academy of Marketing Science, vol. 16, no. 1, pp. 74-94, 1988.

27) F. Falk and N. Miller, Primer for Soft Modeling. Akron,OH: University of Akron Press, 1992.

28) Amin Muslim and Zahora Nasharuddin Siti, "Hospital service quality and its effects on patient satisfaction and behavioural intention," Clinical Governance: An International Journal, vol. 18, no. 3, pp. 238-254, Jan. 2013, doi: 10.1108/CGIJ-05-2012-0016. 